\section{Homemade Floral Preservatives Affect Postharvest Performance of Selected Specialty Cut Flowers}

\author{
Iftikhar Ahmad ${ }^{1,2,3}$ and John M. Dole ${ }^{1}$
}

ADDITIONAL INDEX WORDs. aluminum sulfate, citric acid, folk recipes, lisianthus, snapdragon, stock, vase life, zinnia

SUMMARY. Effects of homemade or commercial floral preservatives, applied as 48-hour grower treatment or continuous retailer/consumer application, were studied on cut 'ABC Blue' lisianthus (Eustoma grandiflorum), 'Maryland Plumblossom' snapdragon (Antirrbinum majus), 'Mid Cheerful Yellow' stock (Matthiola incana), and 'Deep Red' Benary's zinnia (Zinnia violacea). Cut stems were placed in solutions containing $500 \mathrm{~mL} \cdot \mathrm{L}^{-1}$ lemon/lime soda (soda); $6 \mathrm{~mL} \cdot \mathrm{L}^{-1}$ lemon juice plus $20 \mathrm{~g} \cdot \mathrm{L}^{-1}$ sugar (lemon juice); $100 \mathrm{mg} \cdot \mathrm{L}^{-1}$ citric acid plus $20 \mathrm{~g} \cdot \mathrm{L}^{-1}$ sugar plus $200 \mathrm{mg} \cdot \mathrm{L}^{-1}$ aluminum sulfate (C-AS); $400 \mathrm{mg} \cdot \mathrm{L}^{-1}$ citric acid plus $20 \mathrm{~g} \cdot \mathrm{L}^{-1}$ sugar alone (citric acid), or combined with either $0.5 \mathrm{~mL} \cdot \mathrm{L}^{-1}$ quaternary ammonium chloride (C-QA), or $0.007 \mathrm{~mL} \cdot \mathrm{L}^{-1}$ isothiazolinone $(\mathrm{C}-\mathrm{IS}) ; 10 \mathrm{~mL} \cdot \mathrm{L}^{-1}$ Floralife Clear Professional Flower Food (Floralife); or $10 \mathrm{~mL} \cdot \mathrm{L}^{-1}$ Chrysal Clear Professional 2 (Chrysal), dissolved in tap water, which was also used as control without any added compound. Cut stems of lisianthus and stock had longest vase lives (22.1 and 12.7 days, respectively) when placed in C-IS continuously, while snapdragon and zinnia stems had longest vase lives (22.3 and 16.3 days, respectively) when placed in C-QA solution continuously. Continuous use of soda extended vase life of cut lisianthus, snapdragon, and stock stems, but not zinnia, compared with tap water. Citric acid extended the vase life of lisianthus and stock when used continuously and of zinnia when used for 48 hours. Use of C-AS or lemon juice either had no effect or reduced vase life of the tested species, except lemon juice increased zinnia vase life when used as a 48 -hour treatment. Stems of lisianthus, stock, and zinnia placed continuously in C-IS, C-QA, or citric acid had high solution uptake. No significant differences were observed for vase life of all tested species with short duration (48 hours) application of solutions, except 48 hour use of citric acid or lemon juice increased zinnia vase life compared with tap water. Overall, continuous vase application of the homemade preservatives resulted in longer vase life extension than 48-hour treatment. Among tested preservative recipes, C-IS, C-QA, soda, or citric acid demonstrated best postharvest performance of tested species. However, recipes containing C-AS or lemon juice had detrimental effects and should not be used for handling cut stems of tested species.

$\mathrm{F}$ loral preservatives are widely recommended for cut stems and are extensively used in floral arrangements by wholesalers, retailers, and consumers for extending longevity and maintaining quality (Ahmad et al., 2013b; Çelikel and Reid, 2002; Nowak and Rudnicki, 1990). They maintain water uptake by acidifying

We are also grateful to the North Carolina Agricultural Research Service (NCARS), Raleigh, NC, for partial funding of this study.

The authors are grateful to the Sakata Seed America Inc., MI, for providing stock seeds and Ingram F. McCall, Research Technician, for technical help.

Use of trade names in this publication does not imply endorsement by the NCARS of products named nor criticism of similar ones not mentioned.

${ }^{1}$ Department of Horticultural Science, North Carolina State University, Raleigh, NC 27695

${ }^{2}$ Institute of Horticultural Sciences, University of Agriculture, Faisalabad-38040, Pakistan

${ }^{3}$ Corresponding author. E-mail: iahmad3@ncsu.edu. solutions and controlling microbial growth (McDaniel, 1996) and provide carbohydrates necessary to carry on metabolic activities after harvest (Meyer, 2010). They can improve color development of petals, encourage flower opening, and increase flower head size (Nowak and Rudnicki, 1990).

Several manufacturing companies produce different types and brands of floral preservatives, including hydrators and holding or vase solutions. Hydrators are used immediately after harvest or dry storage to improve water uptake by the stems as these contain acidifying agent without sugars. Holding/vase solutions contain sugars along with acidifiers and biocides, which provide food for maintaining metabolic processes and continued flower opening during vase life.

Among acidifiers, citric acid is the most common compound and is used to lower the $\mathrm{pH}$ of the preservative solutions and control microbial proliferation. Citric acid has been found effective for cut roses [Rosa $\times$ bybrida (Jowkar et al., 2012)], gladiolus [Gladiolus hybrids (Tiwari et al., 2010)], carnations [Dianthus caryophyllus (Kazemi et al., 2012)], tuberoses [Polianthes tuberosa (Jowkar and Salehi, 2006)], and lisianthus (Kiamohammadi and Hashemaabadi, 2011). Citric acid lowers the $\mathrm{pH}$ of cell sap and prevents the blockage of xylem vessels, thereby improving water uptake and extending longevity. It promotes floral opening and maintains postharvest quality of cut tuberose spikes (Jowkar and Salehi, 2006).

Another compound used extensively to lower solution $\mathrm{pH}$ and control detrimental microbes in preservative solutions is aluminum sulfate. It is extensively used as a biocide for cut roses (De Stigter, 1981), lisianthus (Liao et al., 2001), and many other cut flower species. It has also been reported to improve keeping quality and vase life of cut roses (Ichimura et al., 2006) by stabilizing petal anthocyanin contents and lowering $\mathrm{pH}$.

Sugars are the integral component of flower foods, providing essential carbohydrates to the cut stems and continuing metabolic processes necessary for extension of vase life. However, sugars must be used along with antimicrobial compounds to prevent microbial buildup in the

\begin{tabular}{llll}
\hline $\begin{array}{l}\text { Units } \\
\begin{array}{l}\text { To convert U.S. to SI, } \\
\text { multiply by }\end{array}\end{array}$ & U.S. unit & SI unit & $\begin{array}{l}\text { To convert SI to U.S., } \\
\text { multiply by }\end{array}$ \\
\hline 10 & $\%$ & $\mathrm{~g} \cdot \mathrm{L}^{-1}$ & 0.1 \\
10 & $\%$ & $\mathrm{~mL} \cdot \mathrm{L}^{-1}$ & 0.1 \\
29.5735 & $\mathrm{fl} \mathrm{oz}$ & $\mathrm{mL}$ & 0.0338 \\
2.54 & inch $(\mathrm{es})$ & $\mathrm{cm}$ & 0.3937 \\
1 & $\mathrm{mmho} / \mathrm{cm}$ & $\mathrm{dS} \cdot \mathrm{m}^{-1}$ & 1 \\
28.3495 & $\mathrm{oz}$ & $\mathrm{g}$ & 0.0353 \\
1 & $\mathrm{ppm}$ & $\mathrm{mg} \cdot \mathrm{L}^{-1}$ & 1 \\
$\left({ }^{\circ} \mathrm{F}-32\right) \div 1.8$ & ${ }^{\circ} \mathrm{F}$ & ${ }^{\circ} \mathrm{C}$ & $\left({ }^{\circ} \mathrm{C} \times 1.8\right)+32$ \\
& & &
\end{tabular}


solutions (van Doorn, 1997). Among these biocides, silver compounds such as silver nitrate and silver thiosulfate, chlorine compounds such as sodium hypochlorite and sodium dichloroisocyanurate, and several other compounds such as cobalt chloride, 8-hydroxyquinoline citrate or sulfate, quaternary ammonium chloride, or isothiazolinone are used to prevent microbial proliferation in vase solutions. Because of environmental hazards associated with silver compounds and 8-hydroxyquinoline citrate or sulfate and only short-term effectiveness of chlorine compounds, quaternary ammonium chloride and isothiazolinone can be used for handling cut flowers. Quaternary ammonium chloride disinfectant is stable, safe, and effective in controlling germs in vase solutions, particularly when freshly prepared solution is used. Isothiazolinone is another safe, effective, broad-spectrum, and globally approved preservative compound, which can also be used as a biocide in floral preservative solutions (Ichimura et al., 2006). However, limited information is available on effectiveness of these compounds for cut flower longevity.

Several other compounds have been used by the industry as biocides, acidifiers, or both in various homemade floral preservatives. Some of these include lemon/lime soda, lemon juice, vinegar, household bleach, aspirin tablets (Greer and Einert, 1994), pennies, or essential oils of several plant species (Fariman and Tehranifar, 2011; Samiee et al., 2013). However, limited information is available on their effectiveness on cut flowers postharvest longevity and quality. Commercial preservatives are well researched and effective, but not readily available in many parts of the world. In addition, several folk recipes also are being used by the industry and consumers, but limited scientific information is available about their effects on the longevity and quality of cut stems. Therefore, the present studies were conducted to determine the effect of different homemade floral preservatives on four popular specialty cut species. The specific objectives of the studies were to 1 ) develop readily available, environmentally safe, and low-cost floral preservative(s) for growers, florists, and consumers; and 2) evaluate the effects of different ingredients of folk floral recipes being used by the industry. It was hypothesized that the recipes would extend the vase life of tested species as much as commercial preservative solutions.

\section{Materials and methods}

Plant material. Cut stems of 'ABC Blue' lisianthus, 'Maryland Plumblossom' snapdragon, and 'Mid Cheerful Yellow' stock were grown in greenhouse, while 'Deep Red' zinnia were field grown at the Horticultural Field Laboratory, North Carolina State University, Raleigh, during 2011-12, using standard commercial procedures. All experiments were conducted at the Postharvest Laboratory, Department of Horticultural Sciences, North Carolina State University, Raleigh. Stems of all tested species were harvested in the morning before $1000 \mathrm{HR}$, placed in buckets containing tap water, and transported to the laboratory within $1 \mathrm{~h}$ of harvest. On arrival, stems were sorted into 17 similar groups on the basis of stem caliper and number of opened flowers/florets, except zinnia for which stage of development (number of open petals) was considered along with stem caliper while sorting stems. All stems were labeled, recut from the bases to uniform lengths of $45 \mathrm{~cm}$ for lisianthus, snapdragon, and stock, or $35 \mathrm{~cm}$ for zinnia and placed in respective treatments. Solutions used in all experiments were prepared using tap water $[\mathrm{pH} 6.9$, electrical conductivity (EC) $\left.0.32 \mathrm{dS} \cdot \mathrm{m}^{-1}\right]$ and stems were placed in solutions after $\mathrm{l} \mathrm{h}$ of solution preparation. For each experiment, fresh solutions were prepared, used to treat cut stems, and initial $\mathrm{pH}$ and EC recorded.

Treatments included $500 \mathrm{~mL} \cdot \mathrm{L}^{-1}$ nondiet lemon/lime soda [soda ( Dr Pepper/Seven Up, Plano, TX)]; 6 $\mathrm{mL} \cdot \mathrm{L}^{-1}$ lemon juice [lemon juice (100\% Lemon Juice from concentrate; Mott's, Rye Brook, NY)] plus 20 g. $\mathrm{L}^{-1}$ sugar (My Essentials white granulated sugar; DZA Brands, Salisbury, NC); $100 \mathrm{mg} \cdot \mathrm{L}^{-1}$ citric acid plus $20 \mathrm{~g} \cdot \mathrm{L}^{-1}$ sugar plus $200 \mathrm{mg} \cdot \mathrm{L}^{-1}$ aluminum sulfate (C-AS); $400 \mathrm{mg} \cdot \mathrm{L}^{-1}$ citric acid plus $20 \mathrm{~g} \cdot \mathrm{L}^{-1}$ sugar alone (citric acid), or combined with either 0.5 $\mathrm{mL} \cdot \mathrm{L}^{-1}$ quaternary ammonium chloride [C-QA (Greenshield; WhitMire Micro-GEN Research Laboratories, St. Louis, MO)], or $0.007 \mathrm{~mL} \cdot \mathrm{L}^{-1}$ isothiazolinone [C-IS (Kathon CG; Rohm \& Haas, Philadelphia, PA)];
$10 \mathrm{~mL} \cdot \mathrm{L}^{-1}$ Floralife Clear Professional Flower Food [Floralife (Floralife, Waterboro, SC)]; or $10 \mathrm{~mL} \cdot \mathrm{L}^{-1}$ Chrysal Clear Professional 2 [Chrysal (Chrysal, Miami, FL)], applied for 48 $\mathrm{h}$ (holding) or continuously until termination (vase). Tap water was used as control without any added compounds. Stems were placed (three stems per vase) at $21 \pm 1{ }^{\circ} \mathrm{C}$ with $40 \%$ to $60 \%$ relative humidity and a $12-\mathrm{h}$ photoperiod provided by cool-white fluorescent lamps. The lamps provided a photosynthetic photon flux of $\approx 20 \mu \mathrm{mol} \cdot \mathrm{m}^{-2} \cdot \mathrm{s}^{-1}$ as measured at bench level with a 1078 QMSW Quantum meter (Apogee Instruments, Logan, UT).

Measurements. Data were collected daily for vase life (duration from placement of stems in vases in the postharvest evaluation room to the time when individual stems ended), initial and final fresh weight and fresh weight change (of one predesignated stem per vase), dry weight (at termination after drying at $70{ }^{\circ} \mathrm{C}$ for $72 \mathrm{~h}$ ), number of flowers/florets opened during vase life (lisianthus and snapdragon only), water uptake (measured in milliliters from all vases when first stem/species was ended in entire experiment), $\mathrm{pH}$ and $\mathrm{EC}$ changes in vase solutions (measured at termination of first stem/vase), and termination symptoms. Symptoms for termination were recorded as present or not present and included bent neck, leaf wilting or petal fading, necrosis, or wilting for lisianthus; leaf wilting, petal abscission, fading, necrosis, wilting, or stem bending for snapdragon; leaf chlorosis, wilting or petal fading, necrosis, or wilting for stock; and leaf wilting, petal blackening, fading, necrosis, wilting, or stem collapse for zinnia (Ahmad et al., 2013a). Cut stems were observed every day during vase period and a symptom was recorded as present if it occurred on at least one petal, leaf, or bud. Stems were ended when they had developed one or more of the aforementioned symptoms on $\geq 50 \%$ of the flowers, foliage, or stem (Ahmad et al., 2013b). Initial solution $\mathrm{pH}$ and $\mathrm{EC}$ were also recorded.

Statistical analysis. All experiments were completely randomized designs with five replicate vases of three stems each and each experiment was repeated twice. Data were subjected to analysis of variance procedures 
using General Linear Models procedures of SAS (version 9.3; SAS Institute, Cary, NC) and means were separated using Tukey's Studentized range test at $P \leq 0.05$.

\section{Results}

Lisianthus. The longest vase life $(22.1 \mathrm{~d})$ was obtained when stems were placed continuously in C-IS, which was $>6 \mathrm{~d}$ longer than vase life of stems in commercial preservatives (Table 1). Stems kept continuously in all floral preservatives had longer vase life, except C-AS, compared with 48-h applications, all of which had a statistically similar vase life to stems in tap water. C-AS caused rapid leaf wilting and petal fading, which reduced the vase life. Stems kept in soda also developed leaf wilting; however, it appeared later during the vase period and was not apparent enough to negatively affect vase life. Stems in C-IS had highest fresh weight change $(3.6 \mathrm{~g}$ increase in fresh weight compared with initial fresh weight at harvest) during vase period, while those in C-AS for $48 \mathrm{~h}$ and afterward maintained in tap water lost maximum weight $(6.7 \mathrm{~g})$.

Stems placed continuously in citric acid or C-QA had highest solution uptake, while citric acid had greatest number of opened flowers at termination (Table 1 ). Stems in tap water had the least number of opened flowers at termination. Stems treated for $48 \mathrm{~h}$ with homemade floral preservatives had no effect on fresh weight change, solution uptake, number of open flowers, or leaf wilting compared with continuous application. Stems placed continuously in commercial floral preservatives, Floralife or Chrysal, until termination had little or no leaf wilting. Stems in tap water had no petal fading. Solutions or application duration had no effect on bent neck, petal necrosis, or wilting and averaged $33 \%, 0 \%$, or $99 \%$, respectively.

VASE SOLUTION PH AND EC. The initial $\mathrm{pH}$ of soda and lemon juice was slightly higher (0.2-0.4 units) than that of the solutions made with citric acid or commercial preservatives and much lower (3.8-3.9 units) than tap water (Table 2). Overall in all species, the $\mathrm{pH}$ of tap water became more acidic by 0.4 to 0.7 units, soda and lemon juice either stayed constant or decreased slightly $(0.2)$, respectively, and the remaining solutions increased slightly $(0.1$ to 0.2$)[P<0.0001$ (data not presented)]. The initial EC of all solutions with compounds added was higher than tap water, with C-AS having the highest $\mathrm{EC}\left(1.15 \mathrm{dS} \cdot \mathrm{m}^{-1}\right)$. Overall in all species, the vase solution EC increased by $0.09-0.15 \mathrm{dS} \cdot \mathrm{m}^{-1}$ for those treatments in tap water and by 0.22 to $0.31 \mathrm{dS} \cdot \mathrm{m}^{-1}$ for the solutions with added compounds $[P<$ 0.0001 (data not presented)].

Snapdragon. The stems had longest vase life $(22.3 \mathrm{~d})$ when placed continuously in C-QA, which was $>5 \mathrm{~d}$ longer than commercial preservatives and $10 \mathrm{~d}$ longer than stems in tap water (Table 3). Stems placed continuously in soda had similar vase life to those in solutions with commercial preservatives. Use of preservatives for short period of $48 \mathrm{~h}$ was ineffective and all treatments had similar vase life, dry weight, fresh weight change, and solution uptake to the stems placed in tap water. Continuous use of lemon juice until senescence shortened the vase life of cut snapdragon stems $(9.5 \mathrm{~d})$. Stems placed continuously in soda had highest dry weight $(6.1 \mathrm{~g})$ and greatest increase $(1.8 \mathrm{~g})$ in fresh weight during vase period compared with other preservatives. Stems in all preservative solutions, except continuous use of soda until senescence, lost fresh weight during vase period.

Use of C-AS and C-IS, irrespective of application duration, or continuous use of soda, citric acid, or C-QA had low percentage of stem bending (Table 3). Short-term application of C-AS or continuous use of Floralife or tap water had low percentage of leaf wilting. Continuous use of C-IS or lemon juice or shortterm application of Floralife reduced petal fading. Solutions or application duration had no effect on petal abscission, necrosis, or wilting, which averaged $33 \%, 55 \%$, or $98 \%$, respectively.

STOck. The longest vase life $(12.7 \mathrm{~d})$ was recorded when stems were placed continuously in C-IS, which was $5.3 \mathrm{~d}$ longer than stems in tap water (Table 4). Continuous use of C-AS or lemon juice had detrimental effects on cut stock stems and reduced the longevity to 6.4 or $7.6 \mathrm{~d}$, respectively, compared with other solutions. However, application of C-AS or lemon juice for $48 \mathrm{~h}$ only had no negative effects on longevity and quality of cut stems. Floral preservatives applied for short duration of $48 \mathrm{~h}$ had no effect on vase life, dry weight, fresh weight change, or leaf wilting. Stems placed continuously in soda had highest dry weight $(7.0 \mathrm{~g})$. Stems in C-IS had higher fresh weight at termination compared with initial fresh weight, while stems in all other solutions, irrespective of application duration, lost fresh weight during vase period (Table 4).

Commercial preservatives effectively controlled leaf wilting of cut stock stems irrespective of the application time (Table 4). Short-term application of citric acid or continuous use of soda also controlled leaf wilting. Continuous use of C-AS or lemon juice had highest leaf wilting. Stems kept continuously in C-AS also had high leaf chlorosis and petal fading. Stems placed in 48-h application of soda or tap water had the least leaf chlorosis. Petal necrosis or wilting was unaffected by solution or application duration, and averaged $99 \%$ or $100 \%$, respectively.

Zinnia. Continuous use of CQA resulted in longest vase life (16.3 d), which was $7.6 \mathrm{~d}$ longer than stems in tap water (Table 5). Zinnia stems did not tolerate continuous use of CAS or soda, which had a lower vase life of 6.7 or $8.0 \mathrm{~d}$, respectively. Stems placed in citric acid, lemon juice, or soda for $48 \mathrm{~h}$ had a longer vase life than stems in tap water. Commercial preservatives, Floralife and Chrysal, extended vase life when used continuously, but had similar vase life to tap water, when used for 48 h only followed by placement in tap water.

Stems placed continuously in soda or C-IS had highest dry weight and tap water the lowest dry weight (Table 5). Continuous placement of stems in C-IS resulted in higher fresh weights at termination compared with their initial fresh weights, while stems in all other preservative solutions lost fresh weight during vase period with greatest decrease for stems placed continuously in lemon juice or citric acid. No significant differences were observed among short-term treatments for fresh weight change or dry weight of cut stems. Stems placed continuously in C-IS had highest solution uptake, while those placed in Floralife, lemon juice, Chrysal, or C-AS for 48 h had least solution uptake. 


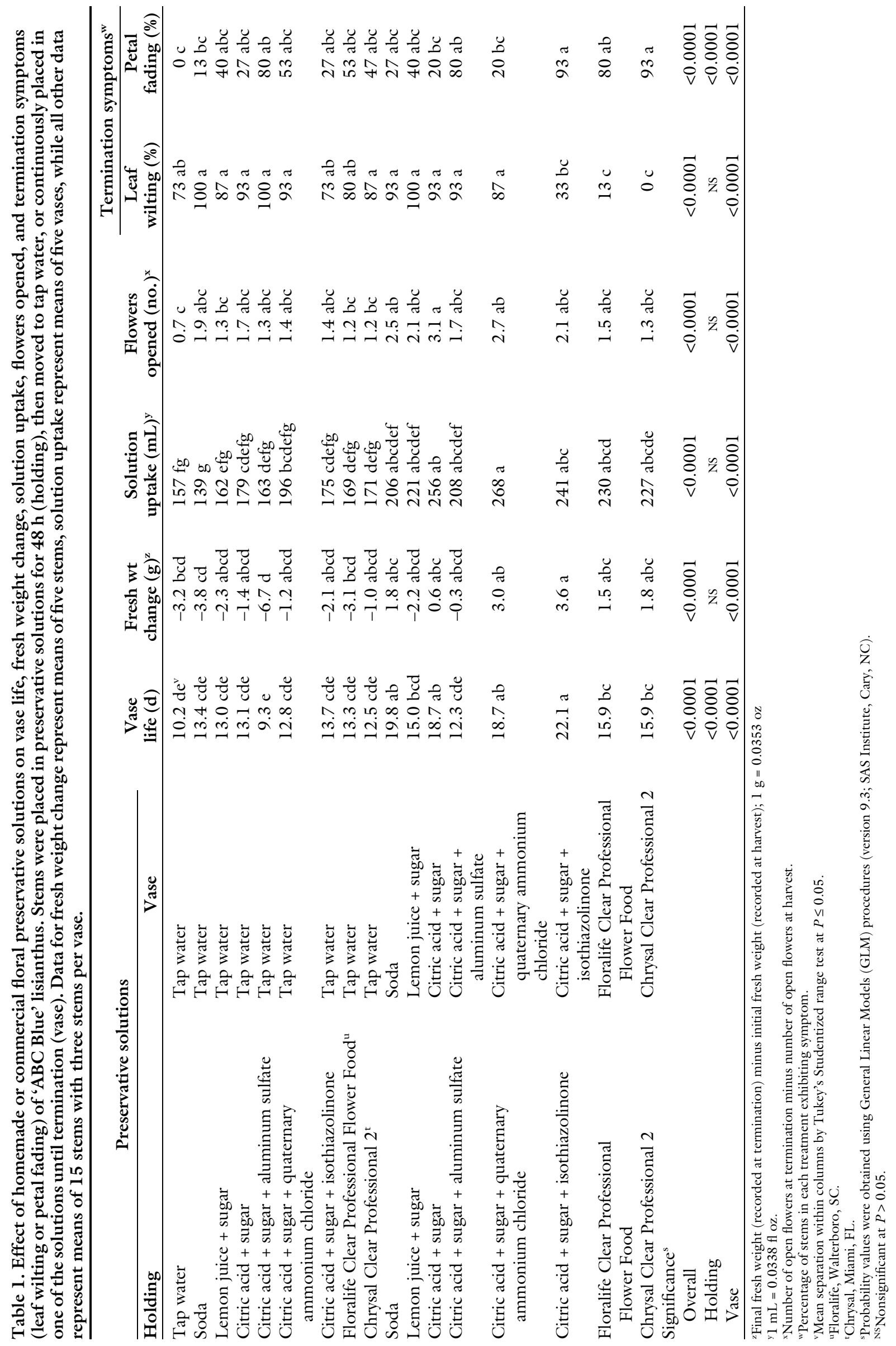


Table 2. Initial pH and electrical conductivity (EC) of homemade or commercial floral preservative solutions. Data represent means of 20 replicate vases of three stems each (five replicate vases for each species).

\begin{tabular}{lcc}
\hline Solutions & Initial $\mathrm{pH}^{\mathrm{z}}$ & Initial EC $\left(\mathrm{dS} \cdot \mathrm{m}^{-1}\right)^{\mathrm{z}}$ \\
\hline Tap water & $6.9 \mathrm{a}^{\mathrm{y}}$ & $0.33 \mathrm{f}$ \\
Soda & $3.1 \mathrm{~b}$ & $0.53 \mathrm{c}$ \\
Lemon juice + sugar & $3.0 \mathrm{bc}$ & $0.45 \mathrm{e}$ \\
Citric acid + sugar & $2.8 \mathrm{~cd}$ & $0.50 \mathrm{~d}$ \\
Citric acid + sugar + aluminum sulfate & $2.7 \mathrm{~d}$ & $1.15 \mathrm{a}$ \\
Citric acid + sugar + quaternary ammonium & $2.8 \mathrm{~cd}$ & $0.53 \mathrm{~cd}$ \\
$\quad$ chloride & & \\
Citric acid + sugar + isothiazolinone & $2.8 \mathrm{~cd}$ & $0.53 \mathrm{~cd}$ \\
Floralife Clear Professional Flower Food & $0.60 \mathrm{~b}$ \\
Chrysal Clear Professional 2 $^{\mathrm{w}}$ & $2.8 \mathrm{~cd}$ & $0.63 \mathrm{~b}$ \\
Significance $^{\mathrm{v}}$ & $2.7 \mathrm{~d}$ & $<0.0001$ \\
\hline
\end{tabular}

${ }^{2}$ Measured when stems were placed in vase solution; $1 \mathrm{dS} \cdot \mathrm{m}^{-1}=1 \mathrm{mmhos} / \mathrm{cm}$.

'Mean separation within columns by Tukey's Studentized range test at $P \leq 0.05$.

${ }^{x}$ Floralife, Walterboro, SC.

wChrysal, Miami, FL.

"Probability values were obtained using General Linear Models (GLM) procedures (version 9.3; SAS Institute, Cary, NC).

Stems treated with commercial preservatives or tap water for $48 \mathrm{~h}$ had highest petal blackening, while use of soda for similar duration had least petal blackening at termination (Table 5). Stems placed continuously in C-AS had no petal fading, which might be due to shorter vase life with this preservative solution, while those with other preservatives had higher petal fading. Stems in tap water or citric acid for $48 \mathrm{~h}$ had no leaf wilting, while those placed continuously in C-AS, lemon juice, or soda had highest leaf wilting. Solutions or application duration had no effect on petal necrosis, wilting, or stem collapse, which averaged $4 \%, 90 \%$, or $25 \%$, respectively.

\section{Discussion}

In these studies, attempts were made to develop readily available, low cost, environment friendly, and effective homemade floral preservative solution(s) of common products to keep cut stems alive and active for a longer period of time and sustain cut stems postharvest life and quality. During preliminary studies, several different recipes being used by the floriculture industry and consumers were compared with two commercial preservatives and tap water on cut roses, lisianthus, marigold, and zinnia stems. The recipes were compared for their short-term $(48 \mathrm{~h})$ or continuous use until senescence of cut stems. Based on the findings of those studies (data not presented), the preservative solution formulations were revised with the objective to have uniform initial $\mathrm{pH}$ of all solutions within optimum range of 2.8 to 3.2 by manipulation of concentration of acidifiers and exclusion of the ingredient(s), which proved detrimental for cut stems of tested species. Among the tested ingredients in preliminary experiments, household bleach and vinegar did not extend vase life of cut stems and increased microbial contamination in the vase solutions particularly when used continuously until termination. These solutions had higher initial $\mathrm{pH}$, which might also be one of the reasons of shorter vase life of cut stems.

Results reported here demonstrated the effectiveness of citric acid and sugar combined with either isothiazolinone or quaternary ammonium chloride as antimicrobial compounds for all four tested specialty cut species. Continuous use of C-IS or C-QA was more effective than commercial preservatives for cut stems of lisianthus and snapdragon or had similar effect to that of commercial preservatives for cut stems of stock and zinnia. Addition of isothiazolinone or quaternary ammonium chloride effectively controlled bacterial populations in the vase solutions (visual observation), had high water uptake, and had low $\mathrm{pH}$ of the vase solution, which might have extended the vase life of cut stems (Gast, 2000). Ichimura et al. (2006) noted that isothiazolinone extended vase life of roses. Stems placed continuously in C-IS maintained the fresh weight of cut lisianthus, snapdragon, and stock stems until termination and either had higher or similar fresh weight at termination as immediately after harvest. It has also been reported that addition of antimicrobial compounds to the vase solutions containing carbohydrates increase fresh weight of cut stems (Marousky, 1980), which might be one of the possible reason for higher termination fresh weights of stems placed continuously in solutions with C-IS.

Interestingly, continuous use of C-IS increased petal fading of cut stems of lisianthus and zinnia, but decreased fading of snapdragon and stock. Increase in petal fading might be associated with longer vase life of cut stems kept continuously in solutions containing C-IS or may also depend on species specific response to the solutions applied for extended period of time until senescence.

Results show the effectiveness of soda and/or citric acid plus sugar alone for vase life extension. Continuous use of soda extended vase life of cut lisianthus, snapdragon, and stock stems, but not zinnia, compared with tap water. Citric acid extended the vase life of lisianthus and stock when used continuously and of zinnia when used for $48 \mathrm{~h}$. For all tested species, cut stems placed continuously in soda had highest dry weight of stems compared with other solutions. Continuous availability of sugars with low $\mathrm{pH}$ in solutions containing soda might have maintained continued metabolic activities and water uptake resulting in maintaining higher dry matter in the cut stems until termination. The use of organic soda or citric acid plus sugar would be compatible with handling organically produced cut stems. Long-term use of citric acid plus sugar might be problematic without an antimicrobial compound, however.

Continuous use of citric acid increased flower opening of lisianthus, which confirmed the role of citric acid in maintaining postharvest quality and increasing color development during flower opening (Jowkar and Salehi, 2006). This would be especially useful for the species harvested at bud stage. Continuous use of citric acid increased leaf wilting of tested species, which might be associated with development of microbial contamination in vase solutions and blockage of water uptake by the cut stems. Use of soda also developed leaf-wilting symptoms; however, the availability of high amounts of sugar in the vase solution may have reduced 


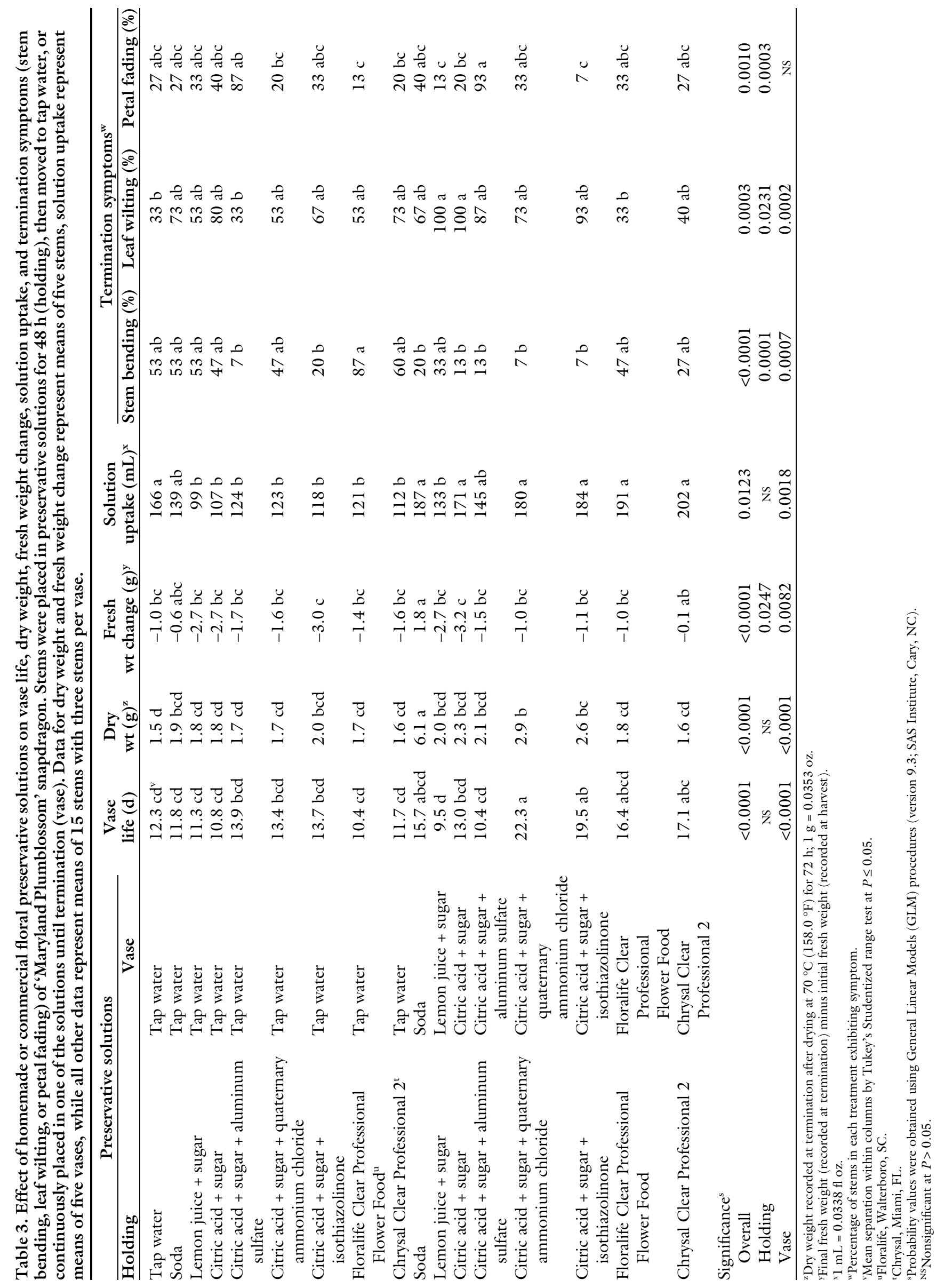




\section{Research Reports}

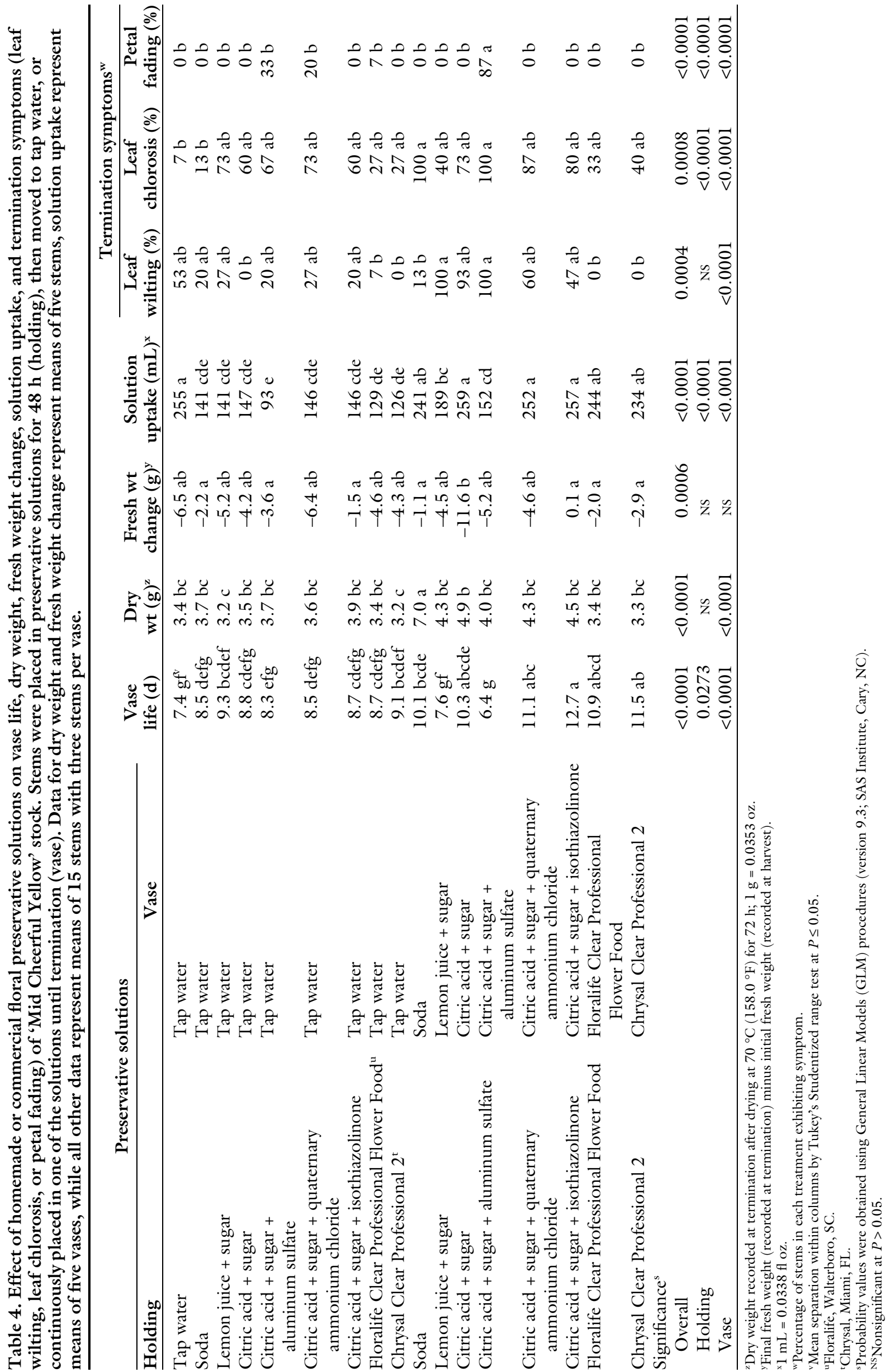




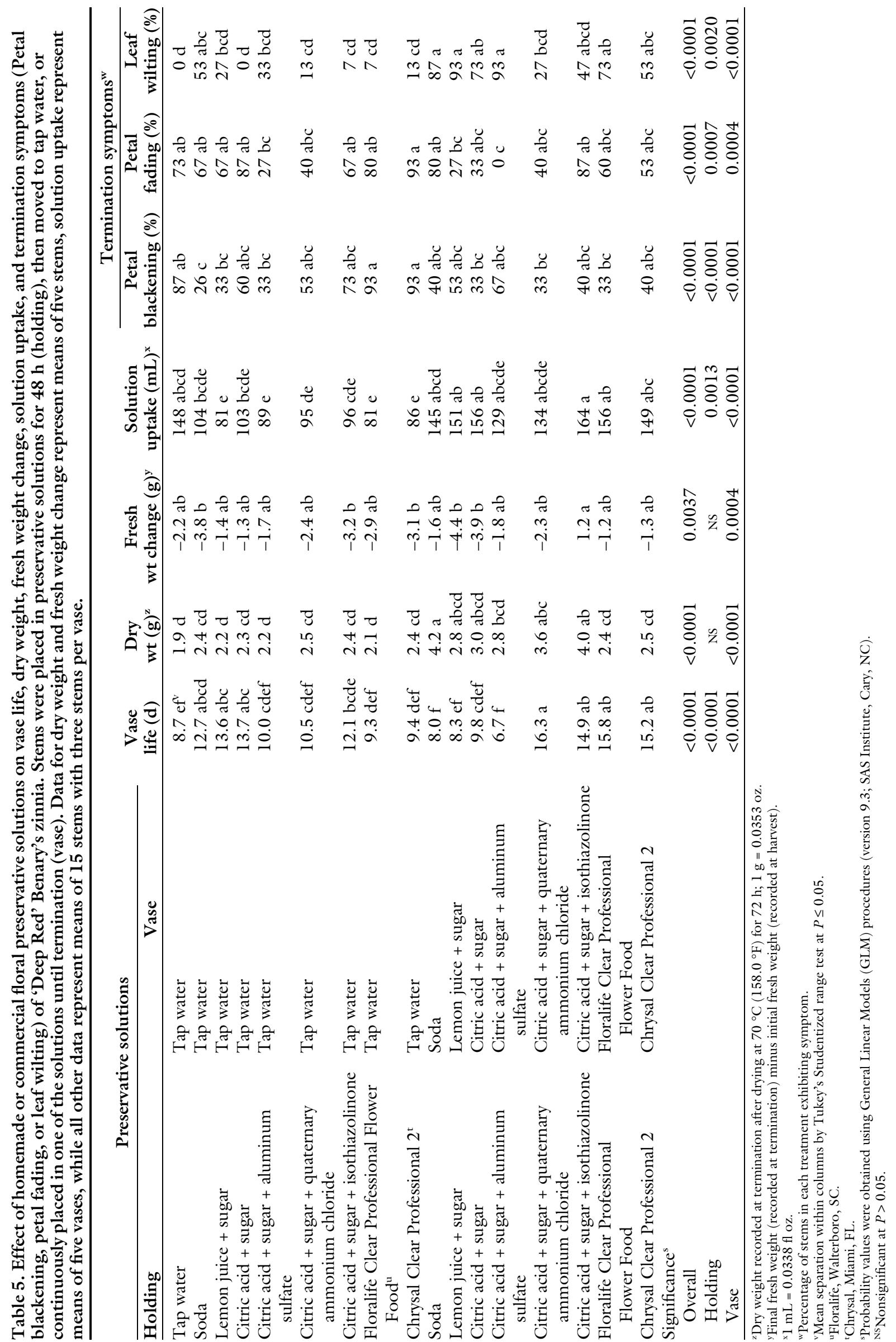


the severity and delayed the appearance of termination symptoms compared with the stems with citric acid.

Continuous use of solutions with soda or citric acid plus sugar developed visible microbial contamination in vase solutions; however, senescence rate was not accelerated for the species tested. These findings suggested the ability of the tested species to withstand the microbes effectively might be due to availability of higher carbohydrates, which delayed the development of termination symptoms in soda or citric acid plus sugar compared with lemon juice or C-AS, which also exhibited microbial growth. This is also evident from higher stem dry weight with soda or citric acid plus sugar than lemon juice or C-AS. Several other species such as carnation (van Doorn et al., 1991) and freesia (Woodson, 1987) have been reported to be unaffected by the presence of microorganisms in the vase solutions. In such species, vascular blockage may not be the sole reason of senescence, which is a combination of some physical (e.g., vascular occlusion due to air embolisms or microbial proliferation) and genetically controlled factors (e.g., loss of membrane permeability) (Woodson, 1991). If solution uptake is not blocked by vascular blockage, genetically controlled loss of membrane integrity may hinder uptake ultimately leading to senescence.

Lemon juice or C-AS either reduced vase life when used continuously, or had no effect when used for short duration of $48 \mathrm{~h}$, except lemon juice increased zinnia vase life when used as a 48-h treatment. On cut lisianthus stems, C-AS resulted in leaf wilting, which might have reduced photosynthetic activity and resultant assimilation rate, and be one of the reasons of shorter vase life. Overall quality of cut stems was negatively affected due to petal fading and wilted foliage. Phytotoxicity of aluminum sulfate has also been reported on other cut flower species including narcissus [Narcissus hybrids (Jowkar, 2005)]. Stems treated continuously with lemon juice or CAS lost highest fresh weight during vase period, which might be due to imbalance between water uptake and water loss through transpiration enhanced due to phytotoxicity and poor water uptake. Presence of microbial colonies in vase solutions with lemon juice or C-AS would have blocked the vascular system, hindering water uptake into the stems, causing leaf wilting/necrosis to occur due to rapid water loss.

Overall, continuous use of preservative solutions had more pronounced effect on vase life extension of all tested species compared with short-term $(48 \mathrm{~h})$ application, which had no differences among homemade or commercial preservatives and tap water, with the exception of citric acid, lemon juice, and soda solutions on zinnia compared with tap water. These results revealed the necessity of continuous provision of carbohydrates and suppression of microorganisms by addition of germicides in the vase solutions for maintaining water uptake and other metabolic processes. Similar findings also have been reported by Elhindi (2012) and Jones and Hill (1993), who reported significance of carbohydrates and germicides for extending postharvest longevity of cut flowers.

These studies demonstrated the potential impact of a few homemade floral preservatives on postharvest longevity of cut lisianthus, snapdragon, stock, and zinnia. Continuous use of preservative solutions resulted in longer vase lives and delayed senescence of all tested species. Among preservative recipes, C-IS, C-QA, soda, or citric acid demonstrated best postharvest performance of cut stems, which may be used by the industry and consumers when commercial preservatives are not available. However, recipes containing C-AS or lemon juice had detrimental effects on the cut stems tested and should be avoided.

\section{Literature cited}

Ahmad, I., J.M. Dole, A.S. Carlson, and F.A. Blazich. 2013a. Water quality affects vase life of cut callas, hydrangeas and snapdragons. Sci. Hort. 153:26-33.

Ahmad, I., J.M. Dole, M. Saleem, M.A. Khan, A. Akram, and A.S. Khan. 2013b. Preservatives and packaging material have an impact on the post-harvest longevity of cut Rosa hybrida L. 'Kardinal' flowers. J. Hort. Sci. Biotechnol. 88:251-256.

Çelikel, F.G. and M.S. Reid. 2002. Postharvest handling of stock (Matthiola incana). HortScience 37:144-147.

De Stigter, H.C.M. 1981. Effects of glucose with 8 -hydroxyquinoline sulfate or aluminum sulfate on the water balance of cut 'Sonia' roses. Zeitschrift fur Pflanzenphysiologie 101:95-105.

Elhindi, K.M. 2012. Effects of postharvest pretreatments and preservative solutions on vase life longevity and flower quality of sweet pea (Lathyrus odoratus L.). Photosynthetica 50:371-379.

Fariman, Z.K. and A. Tehranifar. 2011. Effect of essential oils, ethanol and methanol to extend the vase-life of carnation (Dianthus caryophyllus L.) flowers. J. Biol. Environ. Sci. 5:91-94.

Gast, K.L.B. 2000. Water quality: Why it is so important for florists. Kansas State Univ. Ext. Publ. MF-2436.

Greer, L. and A.E. Einert. 1994. Folk recipes to extend the vase life of cut roses. HortScience 29:736. (abstr.).

Ichimura, K., M. Taguchi, and R. Norikoshi. 2006. Extension of the vase life in cut roses by treatment with glucose, isothiazolinonic germicide, citric acid and aluminum sulphate solution. Jpn. Agr. Res. Qrtly. 40:263-269.

Jones, R.B. and M. Hill. 1993. The effect of germicides on the longevity of cut flowers. J. Amer. Soc. Hort. Sci. 118: 350-354.

Jowkar, M.M. 2005. Effects of different compounds on the microbial population of cut 'Shiraz narcissus' vase solution. Acta Hort. 682:1705-1708.

Jowkar, M.M. and H. Salehi. 2006. The effects of different preservative solutions on the vase life of cut tuberose (Polianthes tuberosa L.) cv. Goldorosht-e-mahallat. J. Sci. Technol. Agr. Natural Resources 10:299-309.

Jowkar, M.M., M. Kafi, A. Khalighi, and N. Hasanzadeh. 2012. Reconsideration in using citric acid as vase solution preservative for cut rose flowers. Current Res. J. Biol. Sci. 4:427-436.

Kazemi, M., E. Hadavi, and J. Hekmati. 2012. Effect of salicylic acid, malic acid, citric acid and sucrose on antioxidant activity, membrane stability and ACC-oxidase activity in relation to vase life of carnation cut flowers. J. Plant Sci. 7:78-84.

Kiamohammadi, M. and D. Hashemaabadi. 2011. The effects of different floral preservative solutions on vase life of lisianthus cut flowers. J. Ornamental Hort. Plants 1:115-122.

Liao, L.J., Y.H. Lin, K.L. Huang, and W.S. Chen. 2001. Vase life of Eustoma grandiflorum as affected by aluminum sulfate. Bot. Bull. Acad. Sin. 42:35-38.

Marousky, F.J. 1980. Inhibition of cut flower bacteria by 8 -hydroxyquinoline citrate. Acta Hort. 113:81-88. 
McDaniel, G.L. 1996. Floral design and arrangement. 3rd ed. Prentice Hall. Upper Saddle River, NJ.

Meyer, M.H. 2010. Keeping cut flowers and flowering plants. 16 Feb. 2010. <http://www.extension.umn.edu/ distribution/horticulture/dg7355.html>.

Nowak, J. and R.M. Rudnicki. 1990. Postharvest handling and storage of cut flowers, florist greens and potted plants. Timber Press, Portland, OR.
Samiee, M., M. Zarchini, S.H. Vand, and D. Hashemabadi. 2013. Improvement of vase life, protein content and postharvest quality of Dendranthema grandiflorum L. cv. White by Artemisia oil. Ann. Biol. Res. 4:127-129.

Tiwari, A.K., B.D. Bhuja, and S.K. Mishra. 2010. Impact of certain chemicals on vase life of different cultivars of china aster and gladioli. Indian J. Hort. 67:255-259.

van Doorn, W.G. 1997. Water relations of cut flowers. Hort. Rev. 18:1-85. van Doorn, W.G., D. Zagory, Y. de Witte, and H. Harkema. 1991. Effects of vasewater bacteria on the senescence of cut carnation flowers. Postharvest Biol. Technol. 1:161-168.

Woodson, W.R. 1987. Postharvest handling of bud-cut Freesia flowers. HortScience 22:456-458.

Woodson, W.R. 1991. Biotechnology of floricultural crops. HortScience 26:10291033. 